\title{
Metabolic Regulations of Human Growth Hormone Secretion
}

\author{
Minoru IRIE \\ The 3rd Department of Medicine, University of Tokyo, Faculty of Medicine, Tokyo and the \\ 2nd Department of Medicine, Gunma University, School of Medicine, Maebashi, Japan
}

Serial levels of Human Growth Hormone (HGH), glucose, and FFA were determined in various states of human subjects.

I. HGH secretion in normal subjects:

(1) After overnight fast and at bed rest during daytime, 9 subjects showed no significant change of HGH levels. In 8 hospital workers, with daily activity and meals, the elevation of $\mathrm{HGH}$ levels was observed 4 hours after breakfast. The $\mathrm{HGH}$ values at this time were widely distributed, but wider distribution was noted in younger (13-14) age group than other (over 15 and adults) group. This difference was more marked in males than females. (2) at night time, all 10 test subjects showed the elevation of HGH levels with the onset of sleep. HGH secretion appeared to be suppressed by the paradoxical sleep which was defined by brain wave. (3) In 5 subjects, blood was drawn at 40 minutes interval during 3 days fasting. Fluctuations and bursts of HGH levels were observed in all cases, and appeared to correlate with those of FFA.

II. Influence to the $\mathrm{HGH}$ secretion of experimental modifications of metabolic states in normal subjects

(1) In 28 subjects, insulin administration $(0.1 \mathrm{u} . / \mathrm{kg})$ caused marked increase of HGH levels. (2) Following $100 \mathrm{~g}$ glucose load in 21 subjects, HGH levels showed the secondary rise at 4 hours. (3) $25 \mathrm{~g}$ of glucose infused intravenously for 20 minutes caused marked secondary rise, but the same amount of glucose infused for 3 minutes caused only slight rise. The results suggest that the changing of blood glucose level per se may not directly be correlated with the level of HGH. (4) L-arginine administration (20g) caused marked elevation of HGH levels in 5 cases. (5) Ingestion of $70 \mathrm{~g}$ cheese in 6 subjects caused rise of $\mathrm{HGH}$ between 150 and 240 minutes. (6) Ingestion of $50 \mathrm{~g}$ butter in 6 subjects caused no change of HGH levels. (7) For the purpose of decreasing FFA levels, intravenous administration of nicotinic acid $(100 \mathrm{mg} \times 2)$ was performed in 17 subjects. There was a temporary decrease of FFA, followed by a marked secondary rise. HGH levels showed marked increase in all subjects. Changing the manner of administration $(100 \mathrm{mg} \times 5)$ caused no essential difference on the rise of HGH levels. In 7 cases, with the combination of nicotinic acid and heparin injection, which inhibited the fall of FFA levels, the rise of HGH was clearly suppressed. The secondary rise of FFA was less than the cases of nicotinic acid injection alone. (8) Oral administration of $3.3 \mathrm{~g}$ of acetylsalicylic acid in 6 subjects also caused the rise of $\mathrm{HGH}$ levels. (9) Administration of heparin could not suppress the $\mathrm{HGH}$ rise caused by insulin or arginine administration. These 
results suggest that the decrease of FFA level is one of the stimulus for the secretion of HGH.

III. Clinical investigations:

(1) Patients with hypopituitarism caused no change of HGH levels following insulin (18 cases), arginine (6 cases), and nicotinic acid (6 cases) administrations. The marked decrease of the secondary rise of FFA following nicotinic acid or arginine administration in these patients was observed. These results suggest that the secreted HGH participate in inducing the secondary rise of FFA in these conditions. (2) Among 14 diabetic patients who had glucose infusion for 3 minutes, 9 patients showed marked rise of HGH levels. 4 out of 5 borderline cases showed marked rise. (3) In 6 obese patients, nicotinic acid administration caused no increase of HGH levels. The continuation of the secondary rise of FFA in these patients was less than the control normal subjects. These results of diabetes and obesity suggest some implication of the abnormality of $\mathrm{HGH}$ secretion in these states.

(pp. 977 986) 


\section{シンポジゥム IV 成長ホルモンの臨床}

\section{1. 成長木ルモン分泌の代謝性調節}

\section{群馬大学医学部鴫谷内科}

東京大学医学部中尾内枓

入江実

\section{I . 緒言}

人血中に微量に存在する成長ホルモン（以下GHと略す）を Radioimmunoassay により測定するととに よつて ${ }^{12}$, , 近年人における GH分泌関する研究の発展がみられる。 GH 分泌は種々の要因により変動す

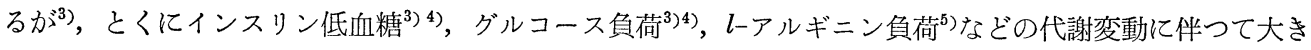

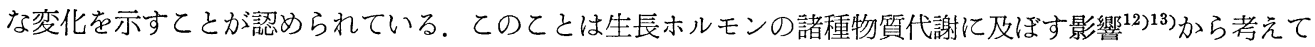
極めて興味強い.

著者は本シンポジウムに於て，先づ正常人に於ける GH 分泌状態，次に実験的に代謝変動を惹起せしめた 場合の正常人及び 2,3 の疾患患者に於ける $\mathrm{GH}$ 分泌状態についての我々の成績について報告する，尚血 中 $\mathrm{GH}$ は濾紙クロマト電気泳動法 ${ }^{12)}$ 或いは 2 抗体法奋により測定し, 血中 $\mathrm{GH}$ 濃度の变化を $\mathrm{GH}$ 分泌変 動と考えて報告する.

\section{II. 正常人に於けるGH分泌状態}

\section{1） $\mathrm{GH}$ 分泌の日内変動}

血中 $\mathrm{GH}$ は運動, 精神的刺激などによつても増 加するといわれ ${ }^{3}$, 我々も精神的, 肉体的安静を 保つととによつて血中 $\mathrm{GH}$ が低下することをしば しば確認している. しかし Fig. 1 上段に示す如く, 前日夕食後より絶食し, 翌日一日安静臥床し, 睡 眠を避け。絶食状態を続け或いは生食の静注を行 い，30分おきに採血し血中 $\mathrm{GH}$ を測定した 9 例で は, 血中 GH はほほ $5 \mathrm{~m} \mu \mathrm{g} / \mathrm{ml}$ 以下でとくに大 きな変動を示さない，尚, 後に述べる種々の負荷 試験は全て同様の条件下で行つたもので上述の成 績を対照としている。病院勤務者 (医師, 研究助 手）8例について日常の活動を行いながらままた 朝食, 昼食も与えた状態で, 経時的に採血, 血中 GH を測定した成績を Fig. 1 中段に示すが，朝食 4 時間後の值が高値を示すととが多いのが認めら れる. 4 例に於て夜間睡眠に際して血中 $\mathrm{GH}$ を測 定したがその結果は Fig. 1 下段に示す如く睡眠中 に上昇を認めることが多い，尚ての問題について
Fig. 1. Diurnal variation of HGH secretion
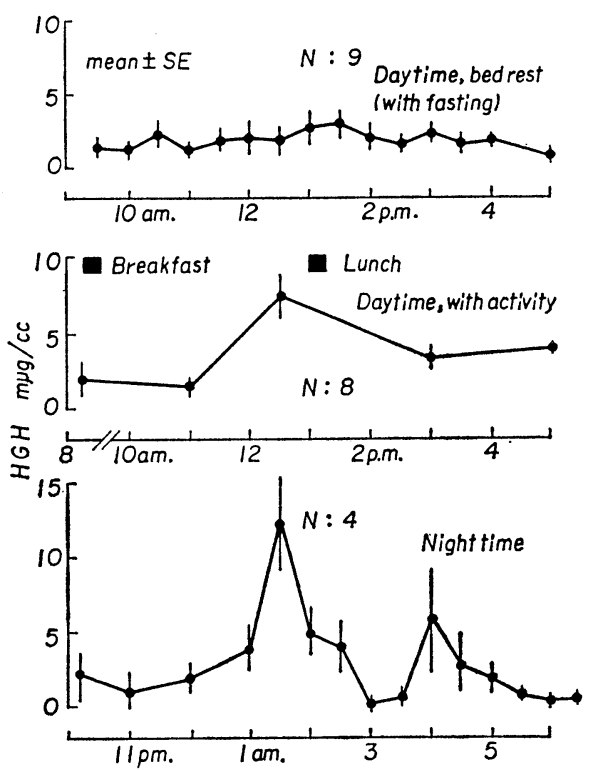
は後述する。

2 ) 朝食 4 時間の血中 $G H$ (Fig. 2)

前述の朝食 4 時間後の血中 $\mathrm{GH}$ 上昇傾向はグ ルコース負荷後の 2 次的上昇 ${ }^{2-4}$ ) 同様の機序に よるものであろうと推定されるが，乙の時間にお ける血中 $\mathrm{GH}$ を13才〜18才の中学, 高校生（双 生児）並びに成人に於て比較するために一定組成, 一定カロリ一の朝食摂取 4 時間後に採血, 血中 GH を測定した. その成績は Fig. 2 亿示す如くで, この時間に於ける血中 $\mathrm{GH}$ は極めて広い分布を 示すが，13〜14才に於ては他に比べて高值を示す ものが多く，乙の時期における $\mathrm{GH}$ 分泌増加を 示唆する成績と考えられる. 女子に於てはこの差 は余り著明でなく，エストロジェン投与が運動時

の GH 分泌を促進するという Frantz らの成績7) と考え併せ女性ホルモンの関与が想定される. 尚13〜18才 の対象において双生児間には血中 $\mathrm{GH}$ の相関関係は認められず，また血中 $\mathrm{GH}$ と身長，体重，，肥満度と の間にも相関関係は認められない.

3 ) 夜間における GH 分泌 (Fig. 3)

この問題については特に東大精神神経科と協同研究を行い，10例の健康男子につき睡眠前及び睡眠中，留 置針より経時的採血を行い血中 $\mathrm{GH}$ 及び血糖值を測定，また同時に脈搏数，脳波を記録し，これらの関連 性につき検討を加えた．そのうち典型的な 2 例についての成績をFig. 3 に示すが，脳波所見は 5 段階に分け 上から下へと深い睡眠に移行するととを示す。血中 GH の上昇は全例に於て脳波上 spindle stage を示す

Fig. 3. Plasma HGH levels and EEG findings during nightsleep

Case 1 . NATURAL SLEEP IN NORMAL SUBJECT T.H.

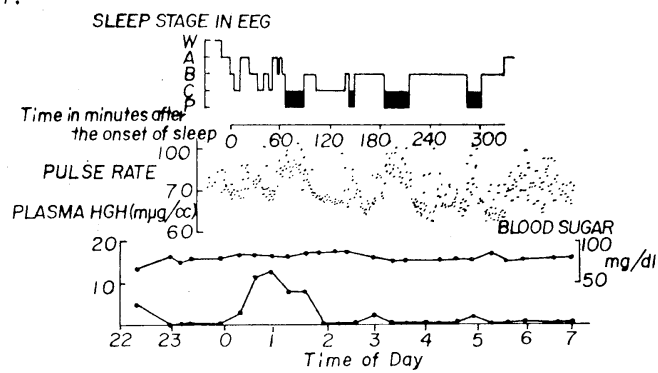

Case 2.

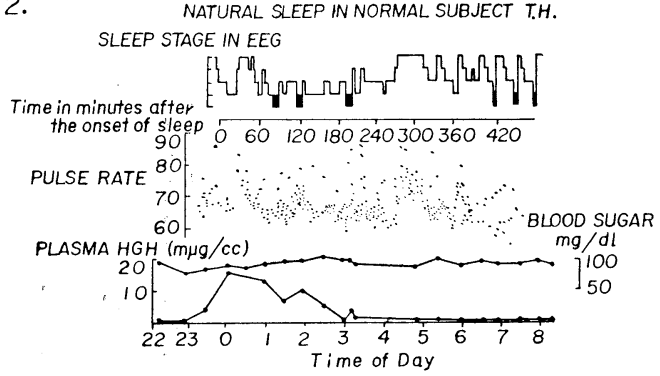

第 44 巻 第 9 号 
入眠期にみられ，以後散発的な上昇を示すとともあるが，全体としては漸減する傾向か認められた．脳波上 いわゆる paradoxical phase を示す時期について細かい検討を加えると, 血中 GH はての時期に低下し始 めるてとが多く，従つて GH 分泌はての段階に於てむしろ抑制されると考えられる。

4) 絶食時の GH 分泌 (Fig.4)

絶食時に GH 分泌が増加するといわれているが3 ${ }^{3}$, 前述したように1 日間の絶食では血中 GH に著明な 変動を認めない，そてで我々は 5 例の正常人男女につき，その後さらに 3 日間にわたる絶食の継続を行い, その間40分間隔にて，留置針より採血し，血中 $\mathrm{GH}$ ，血糖值，血中遊離脂酸（FFA）值につき測定を行つた. その成績をFig. 4 亿示し, 図中横にひいた太い実線は睡眠を示すが第 1 例に於ては軽度の, 他の例に於ては 著明な血中 $\mathrm{GH}$ の変動を認めた。血中 $\mathrm{GH}$ の上昇は乫発的な多くの波によつて形成され，また上昇は夜間 に多く，昼間に於ても睡眠時に多くみられる。図示しないが血糖值は全体として徐々に低下，血中 FFA は 1 日目に上昇, 以後動摇を示し乍ら大体同一レベルを維持した. 血中 GH と血中 FFA との相関について は第 3, 4 例の如く $\mathrm{GH}$ 分泌変動のはげしい例では血中 FFA の変動も大きく, 第 1 例の如く $\mathrm{GH}$ 分泌変動 の少ない例では血中 FFA 変動も少ないという関係が認められた。

Fig. 4. Serum HGH levels during 3-days fasting in 5 cases - sleep

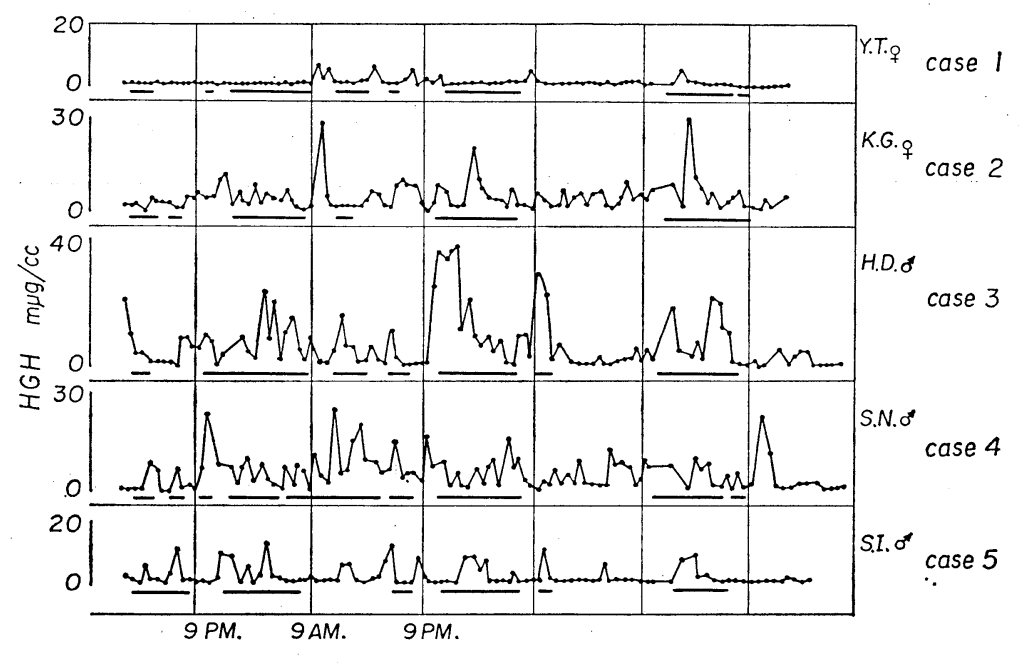

\section{III. 実験的代謝変動に伴う GH 分泌の変化}

緒言に於てのべた如く, インスリン負荷, グルコース負荷, $l$-アルギニン負荷などによる $\mathrm{GH}$ 分泌の変化 はすでに報告されているが，著者はてれらの負荷試験とともに，以下にのべるような諸方法による実験を行 い, GH 分泌の変動に関する検討を行つたのでててに報告する。

1) インスリン負荷 (Fig. 5)

28例の正常人につき早朝空腹時 $0.1 \mathrm{u} / \mathrm{kg}$ の標準インスリンを静注, 前と注射後 30 分間隔にて採血, 血中 GH を測定した成績を Fig. 5 亿示す。乙れはインスリン負荷30分後の血糖が前值の $20 \%$ 上上低下した症例の みの成績であるが，血中 GH は60分をピークとする著明な上昇を示す.

2) グルコース負荷 (Fig. 6，7)

a) 100 グラムグルコース経口負荷 (Fig. 6)

グルコースの経口負荷によつて血中 $\mathrm{GH}$ は一時低下し，4～5 時間後に上昇する 2 相性の変化を示すと いわれている ${ }^{344}$. Fig. 6 に21例の正常人に於て100グラムグルコース負荷を行い経時的に採血, 血中 GH, 
Fig. 5. Effect of insulin administration in normal subjects
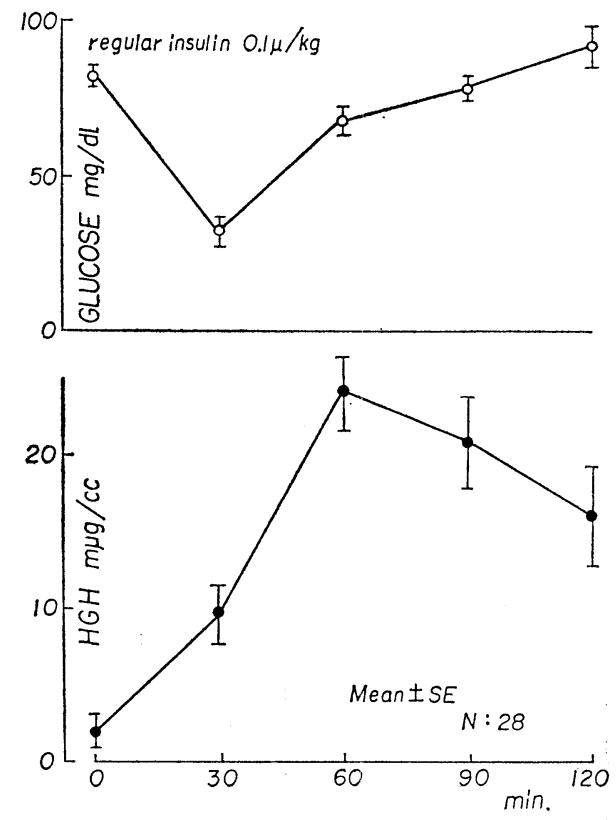

血糖值, 血中 FFA を測定した成績（平均值のみ） を示すがほぼ同様の成績である。

b）グルコース静注負荷 (Fig. 7)

グルコース経口投与 $4 \sim 5$ 時間後の血中 $\mathrm{GH}$ 上昇は，二次的上昇と呼ばれその機序としてRoth ら ${ }^{4}$ は血糖值の急激な下降が刺激となるといい, Hunter $ら^{8)}$ は空腹時血糖值に近いある一定の閾值 を想定し，血糖値がその閥值以下に低下した場合 に GH 分泌が刺激されるとしている. 我々はこ の点につき検討するためにグルコース静注負荷を 行つた. グルコース25グラムを20分間かけて静注 すると Fig. 7 上段に示す如く, 著明な 2 次的上昇 をみることが出来, 従来の説の如く血糖值の変動 と $\mathrm{GH}$ 分泌との間に密接な関係があるようにみ えた. しかし乍ら Fig. 7 下段に示す如く同量のグ ルコースを 3 分間にて急性投与すると，20分投与 の場合よりも急激な血糖值の変動を示すにも拘ら ず，血中 $\mathrm{GH}$ の 2 次的上昇は極めて軽度である ことがみられた。この両者の成績の差異がいかな

る因子によるが現在の所不明であるが，少くとも単に血糖值の変動のみが $\mathrm{GH}$ 分泌と直接関係して 2 次的 上昇を惹起するものとは考えにくい.
Fig. 6. Effect of 100 gram oral glucose administration in normal subjects

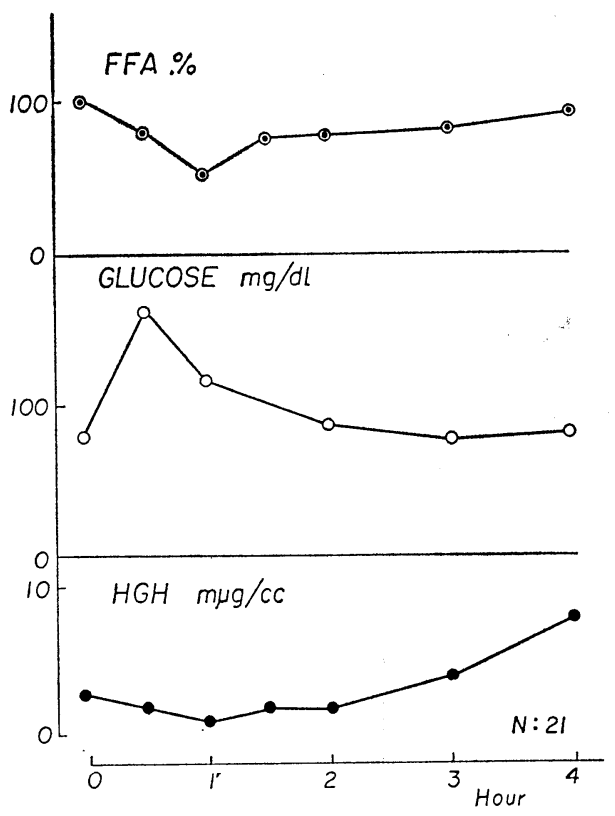

Fig. 7. Effect of intravenous glucose administration in normal subjects

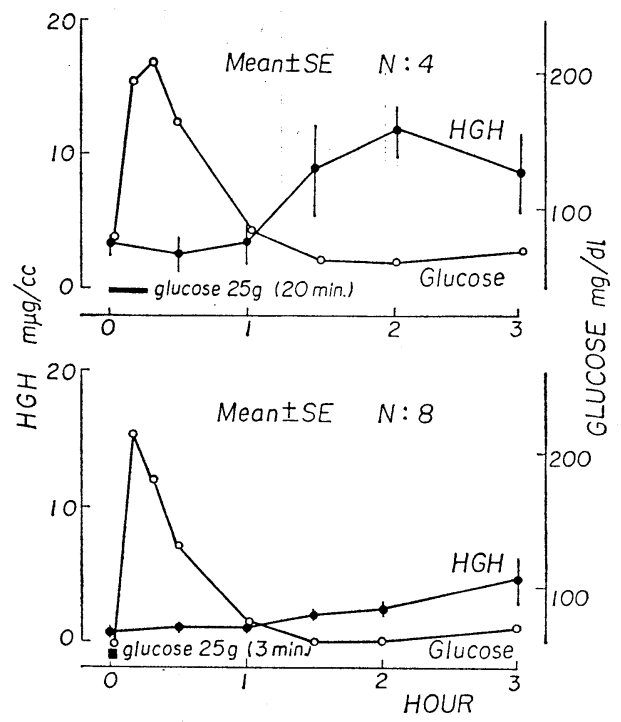


3) l-アルギニン負荷 (Fig. 8)

$l$-アルギニン 20 グラムを正常人 5 例について 30 分間にて点滴静注し, 経時的に採血, 血中 $\mathrm{GH}$, 血糖値, 血中 FFA の測定を行つた．その成績を Fig. 8 亿示すが，血中 GH は著明な上昇を示した，血糖值には有 意の変動なく，血中 FFA は一過性に低下，後に著明に上昇する反応がみられた。

Fig. 8. Effect of $l$-arginine administration in normal, subjects
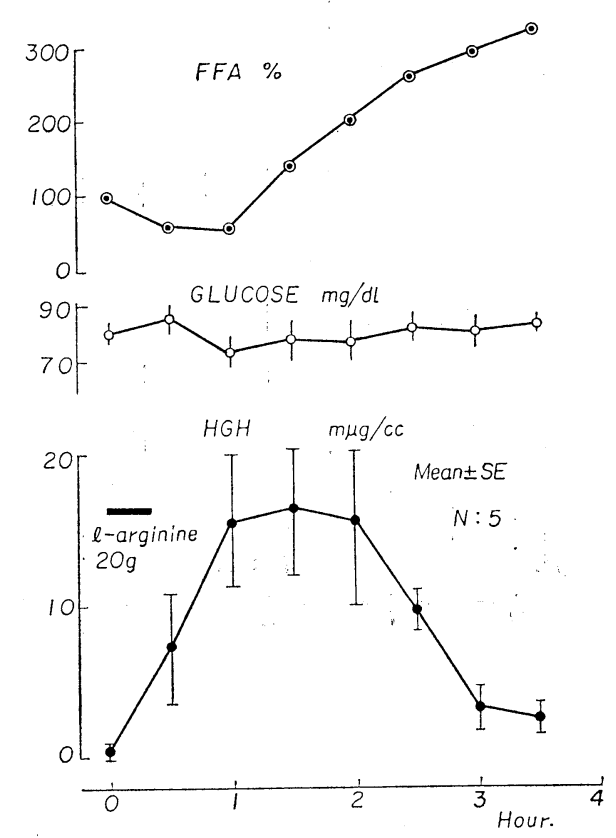

Fig. 9. Effect of protein feeding (Cheese $70 \mathrm{~g}$ ) in normal subjects
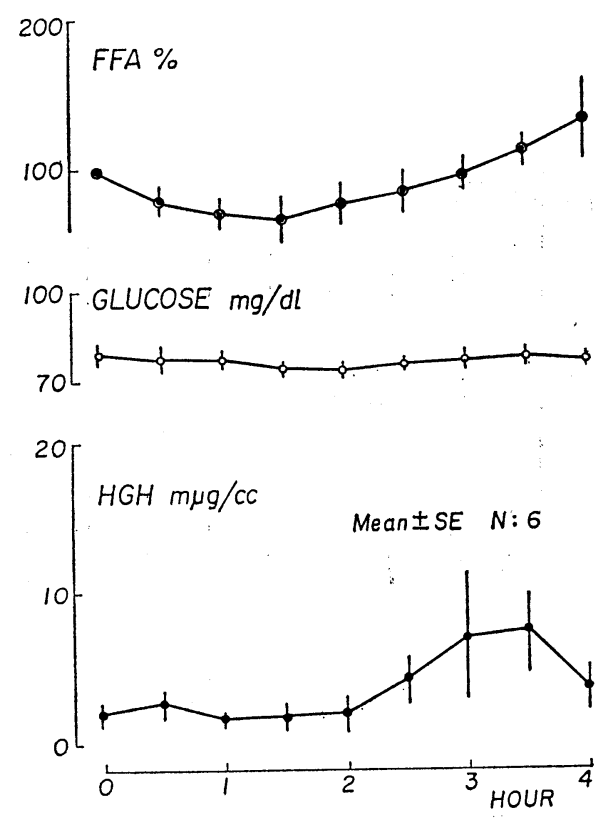

\section{4) 蛋白質摂取 (Fig. 9)}

蛋白質摂取の 1 例として正常人 6 例に於てチーズ70グラムを摄取せしめた。血中 GH は Fig. 9 亿示す如 く食後 2 時間半から 4 時間にかけて上昇を示すものが多いが，その程度及び上昇を示す時間にバラッキが多 くみられた。尚この間血糖值には著変なく，血中 FFA は軽度ではあるがしアルギニン負荷の場合と同様の 変化を示した。

\section{5). 脂肪摂取 (Fig. 10)}

脂肪摂取の影響については現在まで殆んど報告をみない. 我々は正常人 6 例にバター50グラムを摄取せし め経時的に採血，血中 $\mathrm{GH}$ ，血糖值，血中 FFA を測定した。 その成績は Fig. 10 亿示す如く，血中 GH には 大きな変動を認めず，血糖值にも著変なく，血中 FFA は軽度増加を示した。

6） ニコチン酸負荷 (Fig. 11, 12, 13.)

GH の一つの生理作用として GH 投与により脂肪組織の分解が促進され，血中 FFA の増加を来たすと とはすでに確認された事実である $\left.{ }^{912}\right)^{13}$ ，そてで我々は逆に血中FFA を実験的に低下せしめた場合における GH 分泌の変動をみるために, 脂肪組織における分解を抑制する薬物として知られているニコチン酸の投与 を試みた. Fig. 11に示す如く，ニコチン酸 1 回 $100 \mathrm{mg}$ を 0 分と20分に於て静脈内投与を行うと, 血中 FFA は約 1 時間の間前值の $50 \%$ 程度に減少し，以後次第に上昇を続け，3 時間後には約 $300 \%$ そるふ心值を示す. 血糖值にはこの間変動はないが，血中 $\mathrm{GH}$ は 2 時間をピークとする著明な上昇反応を示す．との $\mathrm{GH}$ 上昇 と，FFA 上昇とを時間的に対比してみると前者が後者よりも先に現われているてとが認められる. 
Fig. 10. Effect of fat feeding (Butter $50 \mathrm{~g}$ ) in normal subjects
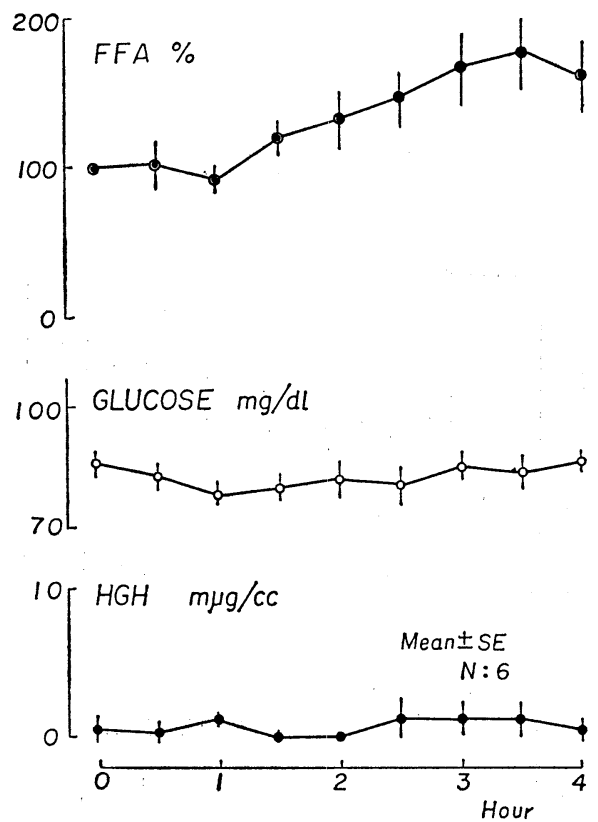

Fig. 12. Effect of nicotinic acid (NA) administration in normal subjects (II)
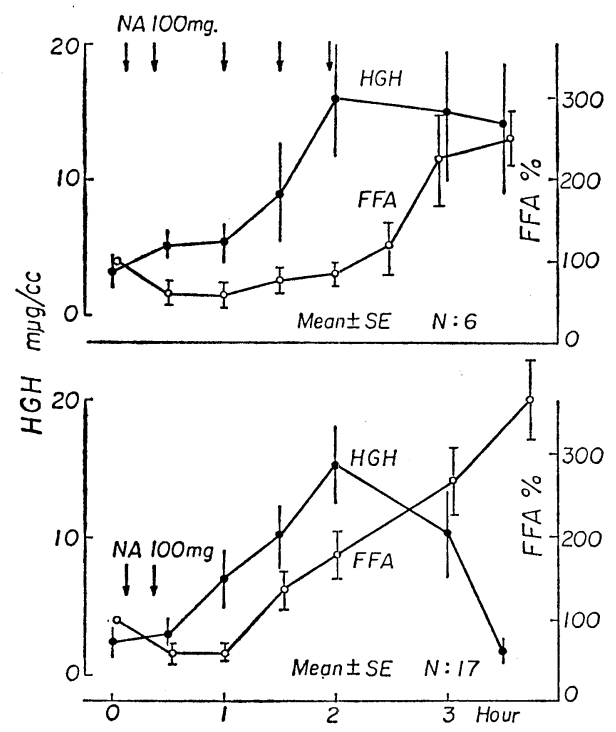

Fig. 11. Effect of nicotinic acid (NA) administration in normal subjects (I)
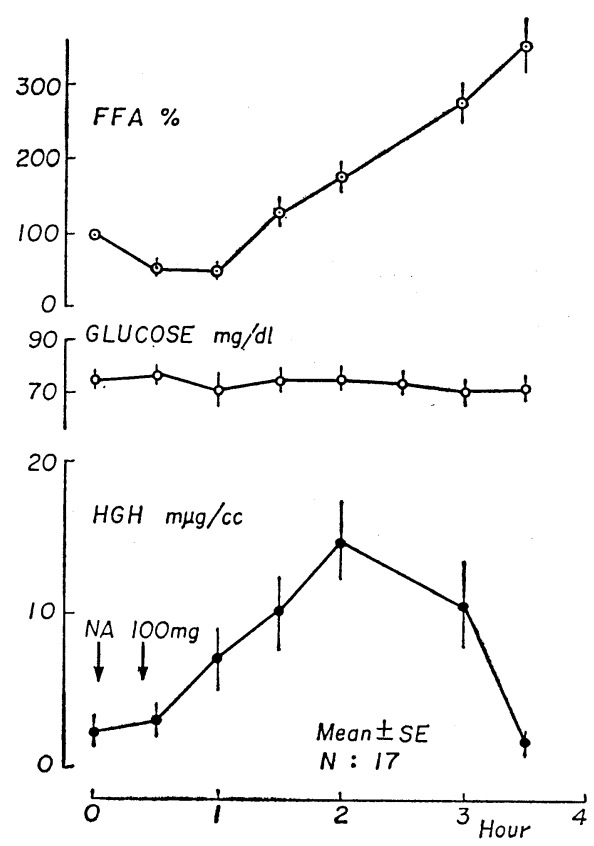

Fig. 13. Effect of the combination of heparin with nicotinic acid administration in normal subjects
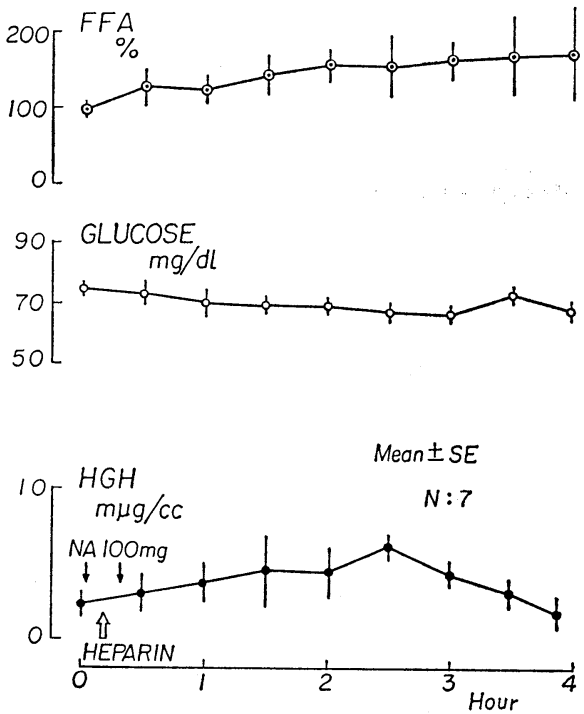

ニコチン酸の投与方法を変えるてとにより，その GH 分泌変動が変化するか否かを調べるために, Fig. 12 上段に示す如きニコチン 1 回 $100 \mathrm{mg} 5$ 回投与と下段に示す如き 2 回投与の場合における血中 $\mathrm{GH}$ 変動に 
つき比較検討した，血中 $\mathrm{GH}$ の上昇は, 両方の場合に於てほぼ同時期に始まり, 且つ同時期にピークに達 し，てのことから GH 分泌刺激となるものは初期における血中 FFA 低下であることが推測される。また 5 回投与の場合, 血中 $\mathrm{GH}$ 分泌増加の継続は 2 回投与にくらべ長期に持続していることがみられ. てれは FFA 低下状態継続による GH 分泌刺激が長く続いているためとも考元られる.

血中 FFA の低下が真に GH 分泌刺激となるか否かを調べる目的で, lipoprotein lipase の活性化により 血中 FFA の上昇をきたすものとして知られているへパリンを, ニコチン酸とともに投与し, その際の GH 分泌変動につき観察した. 即ち Fig. 13 亿示す如く, 7 例において 2 回のニコチン酸投与の間にヘパリン 1000 単位静注を行うと, 血中 FFA の低下は阻害され, 同時に GH 分泌增加も著明に抑制されるととがみられ た。また血中 FFA の 2 次的上昇もニコチン酸単独投与の場合にくらべて明らかに減少した。

7) サルチル酸投与 (Fig. 14)

血中 FFA 低下を来たす他の薬物としてサリチル酸剤が知られている，正常人 6 例について，アセチリサ リチル酸 3.3 グラムを経口技与したが，Fig. 14 亿示す如く血中 FFA 低下，2次的上昇はいづれもニコチン 酸負荷の場合より軽度であつた。 血糖值もやや減少したが血中 GH はニコチン酸負荷の場合よりやや遅れ て上昇を示した。しかしその上昇には個人差, 時間による差が多く認められた。

Fig. 14. Effect of salicylate administration in normal subjects

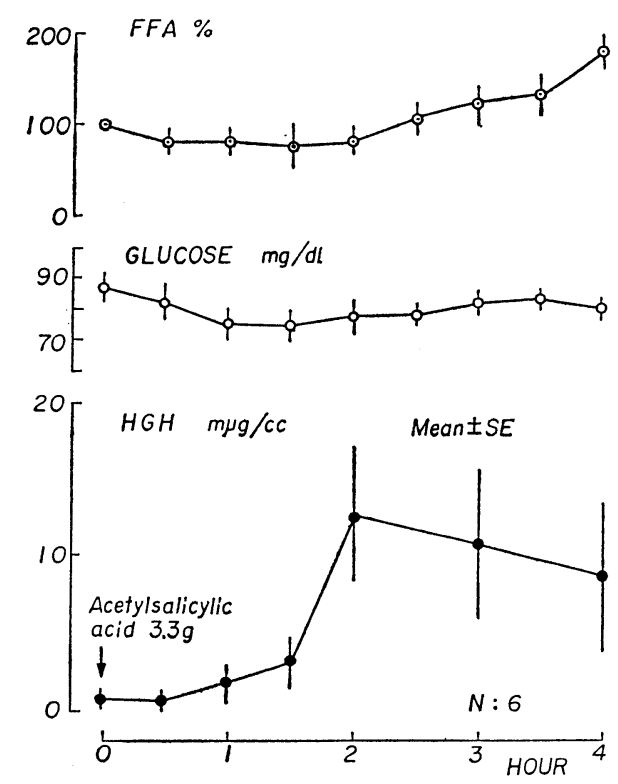

Fig. 15. Effect of the combination of heparin with insulin and $l$-arginine administration in normal subjects

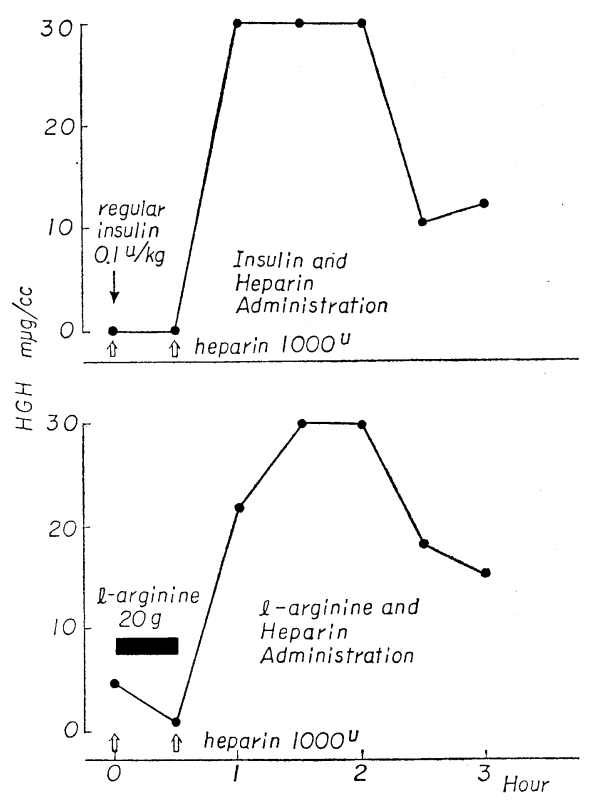

8) インスリン, $l$-アルギニン負荷に対するヘパリン同時投与の影響 (Fig. 15)

前述の如く血中 FFA の低下は GH 分泌刺激となると考えられ. 一方インスリン或いはl-アルギニン単独 投与によつても血中 FFA 低下を来たす. 即ちてれらの投与による血中 FFA の低下が GH 分泌刺激とな る可能性も考えられたので，インスリン或いは $l$-アルギニンの投与と同時にヘパリン1000単位を 2 回投与し 血中 FFA の低下を阻止した. Fig. 15にはその各 1 例づつを示すが，いづれの場合にも著明な GH 分泌増 加をみた。 この点からインスリン或いはlーアルギニン負荷による GH 分泌刺激は, 血中 FFA 低下による分 泌刺激とは別の因子によるものであろうと推定される 


\section{VI. 諸種疾患患者に於ける $\mathbf{G H}$ 分泌}

1) 下垂体前葉機能低下症 (Fig. 16, 17)

諸種原因による下垂体前葉機能低下症患者について，インスリン負荷試験 (18例)， $l$-アルギニン負荷試験 (6 例)，ニコチン酸負荷試験（6例）を行い，血中 GH の測定を行つた. Fig. 16 に正常人におけるこれら 負荷試験の結果と対比した成績を示すが，下垂体前葉機能低下症患者全例に於て GH 分泌増加は殆んどみ られない.

ニコチン酸負荷, $l$-アルギニン負荷の際における血中 FFA の変動を示すとFig. 17 の如くである. いづれ の負荷の場合にも，下垂体前葉機能低下症患者に於ては正常人に比較して血中 FFA の 2 次的上昇反応が明 らかに低下していることがみられる，尚てれらの患者では甲状腺機能ほぼ正常，副腎皮質機能は一部低下を 示す症例もあるが，補充療法を行つている症例に於ても同様の血中 FFA 变動を示した. てれらの患者では 前述の如く, GH 分泌増加を認めない点から, ニコチン酸負荷, $l$-アルギニン負荷後の血中 FFA 2 次的上 昇反応には分泌される $\mathrm{GH}$ の関与が大きいものと推定される。

Fig. 16. Effect of insulin, $l$-arginine, and nicotinic acid administration in normal and hypopituitary subjects
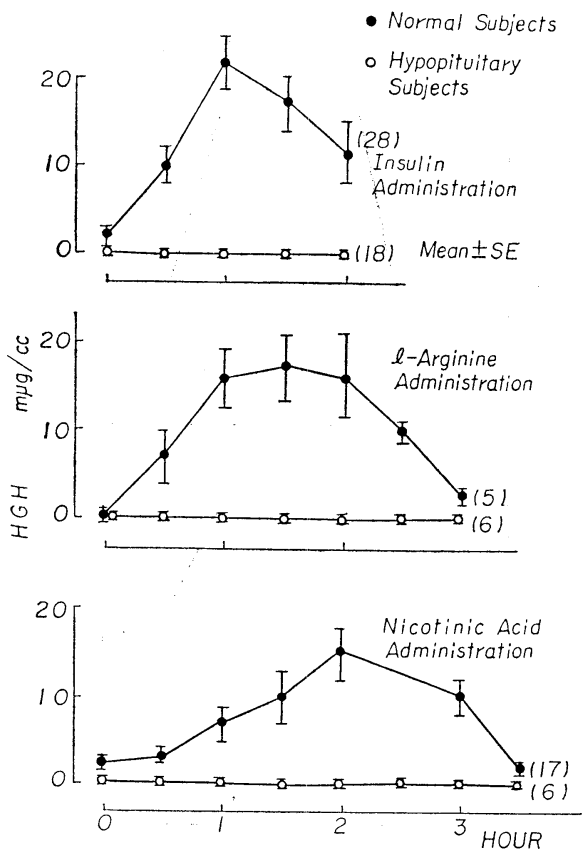

Fig. 17. Serum FFA \% change following nicotinic acid and $l$-arginine administration in normal and hypopituitary subjects
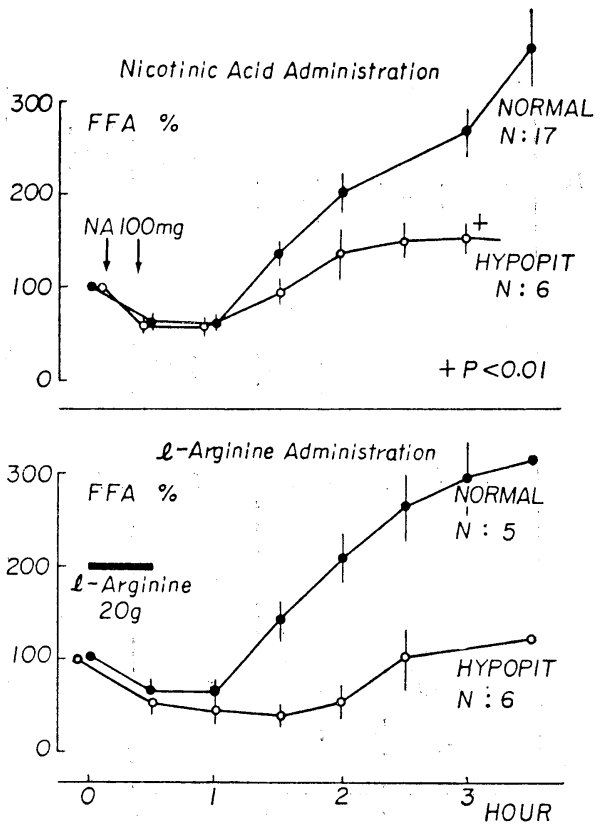

\section{2) 糖尿病 (Fig. 18)}

糖尿病患者14例につきグルコースの 3 分間静注による急性投与を行い, 血中 GH の変動につき観察した. 正常人に於ては前述の如くごく軽度の血中 $\mathrm{GH}$ 増加を認めるのみであるが，糖尿病患者では Fig. 18 に示し た如くグルコース投与後 3 時間の間に著明な血中 $\mathrm{GH}$ の上昇を認めるのもが，14例中 9 例に於て認められ た. てれら患者を 100 グラムグルコース負荷試験の成績によつて糖尿病の重症度によつて分類対比すると， $\mathrm{mg} / \mathrm{dl}$ 以上を示す $\mathrm{A}$ 群に於ては 4 例中 3 例に血中 $\mathrm{GH}$ の上昇をみ，そのうち 2 例は典型的な糖尿病性網膜 空腹時血糖值が 140 症を有していた。 空腹時血糖值が $140 \mathrm{mg} / \mathrm{dl}$ 以下を示した B 群では 5 例中 2 例に血中 
Fig. 18. Effect of intravenous glucose administration (3 minutes) on serum $\mathrm{HGH}$ levels in diabetic subjects
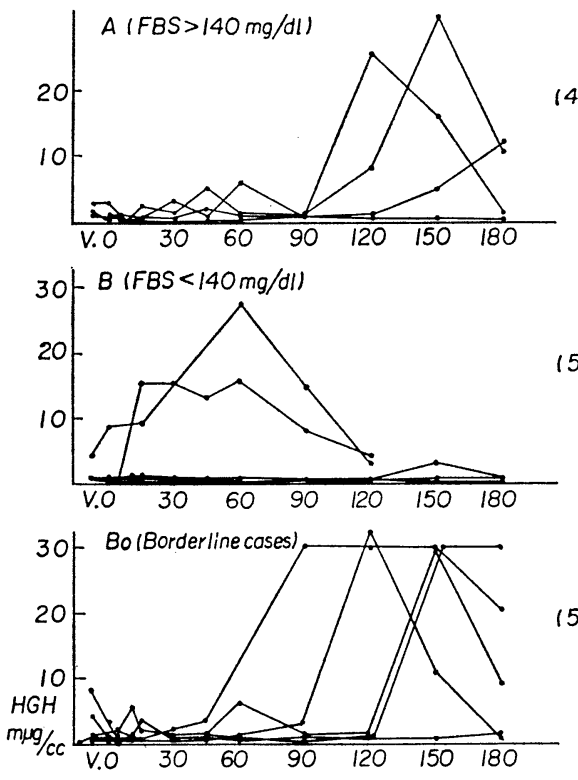

Fig. 19. Comparison of the effect of nicotinic acid administration in obese and normal subjects
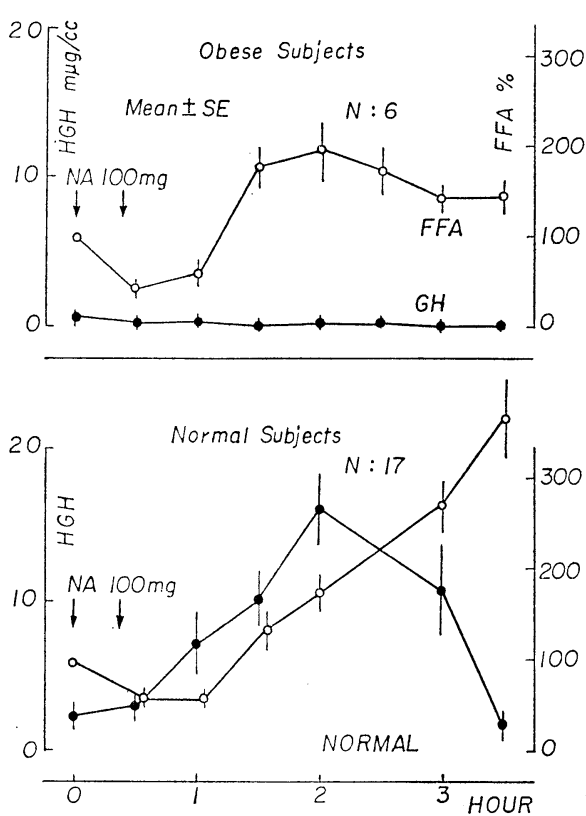

GH の上昇を認め, 他の群にくらべグルコース投与後比較的初期における上昇を示した． 境界例(Bo 群) 5 例では 4 例に於て著明な血中 $\mathrm{GH}$ の增加を示した。乙れらの成績の解釈, 意義に関しては今後さらに検討を 必要とするが, 刺激に対する $\mathrm{GH}$ 分泌過剩と糖尿病の成因乃至進展との相関を示唆する成績とも考えられる.

3) 肥満症 (Fig. 19)

肥満者ではインスリン負荷 ${ }^{10)}, l$ アアルギニン負荷 ${ }^{11}$ 亿よる $\mathrm{GH}$ 分泌は低下しているといわれている。我々 は+20\%以上の肥満度をもつ 6 例の肥満症患者についてニコチン酸負荷を行い，血中 $\mathrm{GH}$ の変動につき観 察した。 その成績はFig. 19 亿示す如くであり全例に於て正常人に於てみられるような GH 分泌增加は全く みられない．またての時の血中 FFA 動態についても肥満症では正常人にくらべて 2 次的上昇の持続が短か いととがみられる。これらの所見は肥満状態と FFA 放出機構, さらに GH 分泌状態という関連性から考 え興味深い所見と考えられる。

\section{V. 結 語}

以上著者は正常人に於ける $\mathrm{GH}$ 分泌状態, 実験的代謝変動飞伴う $\mathrm{GH}$ 分泌の変化, 諸種疾患患者に於け る $\mathrm{GH}$ 分泌, に関する我々の研究成績について述べた，人における $\mathrm{GH}$ 分泌は代謝変動その他数多くの因 子によつて調節をうけ, 諸種状態における GH 分泌状態を形成し, 且つ分泌されたGHは日常における生体 の代謝調節に関与するものであろう．とくに血中 FFA と GH 分泌との相関関係は興味深く, また諸種疾 患, ことに糖尿病, 肥満症における $\mathrm{GH}$ 分泌状態は $\mathrm{GH}$ の生理作用から考えて興味のもたれる研究刘象で あり今後消検討を重ねたい。

\section{謝辞}

終りに臨み, 本シンポジウム参加の機会をお与え頂いた吉田秀雄会長, 本研究に対し終始御指導頂いた中 尾喜久教授, 鴫谷亮一教授, 鎮目和夫講師に深く感謝致します。また御協力を晹つた群馬大学脳神経外科川 
淵純一教授, 東大中尾内科三上理一郎博士, 東大精神神経科本多裕博士, 高橋清久博士, 東京都監察医務院 吉村三郎院長, 奥中雅彦博士, 並びに協同研究者, 東大中尾内科松崎宸博士, 佐久間真樹博士, 対馬敏夫学 士, 群大鴫谷内科堀内宏博士, 大竹誼長博士, 大月邦夫学士, 渡辺明学士の各位に愿く感謝致します.

質問：京府医大吉田内科 福井嚴 我々も HGH の測定を始めたばかりで少しのdataしかありま せんが, 糖尿病の合併症特に網膜症を存するものの血糖 HGH の反応は如何でしょうか. 糖尿病で網膜症を 有するとき下垂体摘除や下垂体の Radiationtherapy が行なわれるか.

応答：東大中尾科内 入江実 講満中に述べたように, ブドウ糖静注負荷試験に際して糖尿病患者 では血中 $\mathrm{GH}$ の上昇を示すむのがみられた。網膜症を有するすの 2 例に於ても著明な上昇がみられたが今 後この点につき検討したい.

\section{文献}

1) GLIGK, S.M., J. ROTH, R.S. YALOW and S.A. BERSON : Nature 199 : 784, (1963)

入江実, 佐久間真樹：日内分泌誌 $42: 475$, (昭41) and S.A. BERSON : Rec. Prog. Hormone Res. 21 : 241, (1965)

R.S. YALOW, and S.A. BERSON : Diabetes $13: 355$, (1964)

3) GLIGK, S. M., J. ROTH, R.S. YALOW, 4) ROTH, J., S.M. GLIGK, 5) KNOPF., R.F. J.W. GONN, S.S. FAJANS, J.G. FLOYD, E.M. GUNTSGHE, and J.A. RULL : J. Glin. Endocr., 25 : 1140, (1965) 6）対馬敏夫，入江実，鎮目和夫，中尾喜久：第 7 回日本核医学会総会発表（昭42）

7) FRANTZ, A.G., and M.T. RABKIN : J. Clin. Endocr., 25 : 1470, (1965) CLARKE, L.J.P. DUNGAN : Metabolism $15: 596$, (1966) LENBERG : J. Glin. Invest. $38: 484$, (1959) 8) HUNTER, W.M., B.F. 9) RABEN, M.S. and C.H. HOLWINTERLING, M.F. STEIN, W.H. DAUGHADAY, and D.M. KIPNIS : J. Lab. \& Glin. Med. 64 : 654, (1964) 11) COPINSCHI, G., L.G. WEGIENKA, S. HANE, and P.H. FORSHAM : Metabolism $16: 485$, (1967) 12$)$ KNOBIL, E. and J. HOTCHKISS : Ann. Rev. Physiol. 26 : 47, (1964) 13）入江実：現代内科学大系 1966-a，293，（昭41） 